\title{
Rola Kazimierza Twardowskiego w filozofii niemieckiej na przełomie XIX i XX wieku (autoreferat)
}

DOI: http://dx.doi.org/10.12775/RF.2018.006

Dnia 5 marca 1938, na 366. plenarnym posiedzeniu naukowym, poświęconym pamięci Założyciela, Przewodniczącego i Członka Honorowego, Prof. dr. K. Twardowskiego, dr L. Blaustein wygłosił odczyt pt.: „Rola Kazimierza Twardowskiego w filozofii niemieckiej na przełomie XIX i XX wieku". Prelegent omówił rolę wydanej w roku 1894 książki Kazimierza Twardowskiego pt.: „Zur Lehre vom Inhalt und Gegenstand der Vorstellungen" na tle ówczesnej sytuacji panującej w filozofii niemieckiej. Następnie scharakteryzował w głównych zarysach dalszy rozwój zagadnienia aktu, treści i przedmiotu, późniejsze zastosowania tego rozróżnienia oraz echa innych, ważniejszych tez „Zur Lehre”. W szczególności zaś uwzględnił prelegent te donioślejsze twierdzenia Twardowskiego, w których wyprzedził on innych uczniów Franciszka Brentany, np. Meinonga, i zwrócił uwagę na fakt, iż w „Zur Lehre” po raz pierwszy dokonano syntezy poglądów Brentany z teorią niedocenianego wówczas filozofa Bolzany. "Odkrycie” Bolzany, dokonane przez Kazimierza Twardowskiego, niesłusznie przypisywali niektórzy niemieccy historycy filozofii innym uczniom Brentany. 